\title{
Influence of seed treatment with mineral nutrient products on emergence and growth in spring oilseed rape (Brassica napus L.)
}

\author{
Eva Stoltz ${ }^{1}$ and Ann-Charlotte Wallenhammar ${ }^{1,2}$ \\ ${ }^{1}$ Rural Economy and Agricultural Society, PO Box 271, SE 70145 Örebro, Sweden \\ ${ }^{2}$ Swedish Agricultural University, Department of Crop Production Ecology, PO Box 7043, SE-751 07 Uppsala, Sweden \\ e-mail: Ann-Charlotte.Wallenhammar@hushallningssallskapet.se
}

\begin{abstract}
Seed treatment with mineral nutrients in spring oilseed rape (SOR) under cold climatic conditions has the potential to improve the outcome of production. The objectives of this study were to investigate the effects of mineral nutrients applied as seed treatment on germination and growth of roots and biomass in SOR. In addition, seed yield and oil content were also measured. Seed vigour tests and in-field experiments were performed in Central Sweden in 2016 and 2017. Seven products with different composition of mineral nutrients were applied to the seed in a combination with binder, filler and fungicide (BFF), or applied directly onto the seed. The results showed that a treatment with mineral nutrients increased the plant size at stage $\mathrm{BBCH} 60$ (early flowering stage) when the products were applied in combination with BFF in the field experiments. However, the increased plant size did not influence seed yield. Furthermore, when seeds were treated only with a nutrient product the addition of BFF decreased plant size by $10 \%$ on average and seed and crude fat yields by $4 \%$ on average. The use of BFF may thereby be questioned and is subject to further investigation.
\end{abstract}

Key words: seed treatment, mineral nutrients, spring oil seed rape, Brassica napus

\section{Introduction}

The flowering rapeseed fields represent an important cornerstone of Nordic crop production. Production of rapeseed oil and rapeseed meal provides valuable food and feed with a balanced nutritional composition, and increased use of rapeseed as an energy source is an important step towards a sustainable bioeconomy. Spring oilseed rape (SOR) (Brassica napus L.) is a profitable branch of production, however, with sharply decreased acreage in Sweden as a result of major insect problems. Cultivation of SOR is often associated with high pressure from insect pests. Flea beetles (Psylliodes spp), blossom beetles (Brassiogethes aeneus), and diamondback moths (Plutella xylostella), threaten crops and thus an extensive use of insecticides is needed (Williams 2010, Ekbom 2010). To reach an environmentally sustainable SOR production, alternative measures need to be considered. It is confirmed that the concentration of mineral nutrients in the seed influences germination and early growth, e.g. manganese and zinc in wheat, phosphorus in narrow-leafed lupin, phosphorus and molybdenum in common bean and boron in red clover seed (Marcar and Graham 1986, Rengel and Grayham 1995, Thomson et al. 2008, Sanches Pacheco et al. 2012, Stoltz and Wallenhammar 2014). Previous investigations showed enhanced germination and growth in a number of other crops e.g. oats, wheat, black seed, maize, by seed treatments with nutrients such as iron, boron, zinc, manganese, phosphorus, sodium, copper, and cobalt (Peltonen-Sainio et al. 2006, Mirshekari 2010, Farooq et al. 2012, Imran et al. 2013, Seyvedi et al. 2015). Thus, the treatment of seeds with mineral nutrients may be a new and innovative method to improve emergence and growth of SOR, hence reducing damage from flea beetles. Seeding early at low soil temperatures $\left(<10^{\circ} \mathrm{C}\right)$, when the flea beetles are inactive, is practised by Swedish farmers to reduce the damage. When the soil temperature is low, plant nutrients may not be readily available for the germinating seedlings. The plant availability varies for different nutrients, i.e. at low temperatures $\left(<10^{\circ} \mathrm{C}\right)$ the plant uptake of $\mathrm{P}$ and $\mathrm{K}$ is reduced while the uptake of $\mathrm{Ca}$ and $\mathrm{Mg}$ are not as significantly affected (Miyasaka and Grunes 1990, Engels and Marschner 1992).

A major part of the investigations on seed treatments with mineral nutrients has been performed by soaking the seeds in solutions for several hours (Ullah et al. 2002, Mirshekari 2010, Farooq et al. 2012, Imran et al. 2013, Seyvedi et al. 2015). In practice, soaking of seeds is not appropriate for farmers who need more efficient methods for seed treatment.

When treating seeds with fungicides or pesticides, liquid binders and powdery fillers are commonly used as a carrier of the active ingredient (Pedrini et al. 2017), and interestingly the effects of these products on germination and growth are not reported.

The objectives of this study were to investigate the effects on germination and root and biomass growth in SOR by applying mineral nutrients as seed treatment. In addition, yields of crude fat and seed were measured. 
The hypotheses were: i) seed treatment with mineral nutrients will enhance germination and growth of SOR at low temperatures i.e. $<10^{\circ} \mathrm{C}$, and ii) The improvement of germination and growth with products containing macro- and micro-nutrients will be higher than that with products containing solely micronutrients.

\section{Materials and methods}

\section{Seed treatment}

Seeds of SOR (cv. SW Majong) were treated with seven different products containing mineral nutrients: Omex

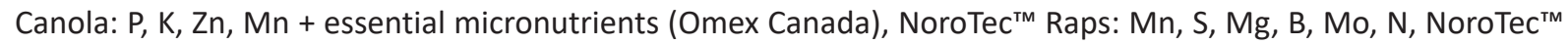
WinterCrop Plus: P, Mg, S, Mn, Zn, N, NoroTec ${ }^{\mathrm{TM}} \mathrm{Zn}$ : P, Mg, S, Mn, Zn, N (NoroTec ${ }^{\mathrm{TM}}$, Sweden), Yara F3493: P, K, Zn, Mn, Yara F3501: P, K, Zn, Yara 3516: P, Mn, Zn, Cu (Yara, Sweden). The dose applied was $6 \mathrm{mg} \mathrm{kg}^{-1}$ seed for all products. The products were applied to the seed mixed with a binder $4 \mathrm{~g} \mathrm{~kg}^{-1}$ of seed (Sepiret 386 Blue, BASF), a filler $5 \mathrm{~g} \mathrm{~kg}^{-1}$ seed (talc, Sepiret PF16 White, BASF) and a fungicide $5.8 \mathrm{~g} \mathrm{~kg}^{-1}$ seed (Rovral $500 \mathrm{~A}$, iprodione) (+ BFF) (Bayer Crop Science) in 2016 and 2017. In 2017, seeds were also treated with nutrient solutions without adding BFF (-BFF), thus, the nutrient products were sprayed directly onto the seeds and the number of treatments was duplicated. There were also controls without nutrient application. In 2016, the control was treated with BFF (control + BFF), and, in 2017, there was one control treated with BFF (control + BFF) and one control treated solely with water $\left(6 \mathrm{ml} \mathrm{kg}{ }^{-1}\right.$ seed) (water - BFF). The seed treatments were performed in an industrial batch seed treater (Satec Concept ${ }^{\circledR}$ ML2000, Agritema, Kiev, Ukraine) at the Rural Economy and Agricultural Society, Department of Seed Technology, Bjärred, Sweden. Each seed treatment was performed in four replicates.

Seeds with and without application of BFF were analysed for mineral nutrients in 2016 (N, P, K, Ca, Mg, Na, S, Cu, Zn, B, Mn, Fe and Al) at Eurofins Agro Testing, Kristianstad, Sweden. Seeds treated with mineral nutrients, without BFF, were analysed for mineral nutrients in 2017, as described above. The BFF products used in this investigation were analysed for Cu, Fe and Al (Eurofins Food \& Agro Testing Sweden AB, Lidköping, Sweden).

\section{Seed vigour test}

Seed vigour tests were performed in dishes $(18 \mathrm{~cm} \varnothing)$ with moist sand (1 part sand:0.075 part water V:V). Fifty seeds were evenly distributed on a thin layer (125 g) of sand in each dish, thereafter the seeds were covered with an additional $500 \mathrm{~g}$ of moist sand and pressed with the bottom of a similar dish. The dishes were covered with a transparent glass cover $(22 \mathrm{~cm} \varnothing)$. The dishes were kept in a dark climate chamber at a temperature of $+6{ }^{\circ} \mathrm{C}$ for 10 days, thereafter in $+20^{\circ} \mathrm{C}$ and light ( 24 hours photoperiod) until emergence. The numbers of emerged seedlings were counted at regular intervals. The seed vigour were tested in four replicates at the Seed Testing Station, Frökontrollen AB, Örebro, Sweden.

\section{Field experiments}

Two field experiments were established yearly in 2016 and 2017, with the treatments described above. The experiments were set up according to a randomised block design with four replicates for each treatment. Location, dates of seeding and harvest, N-application (Yara Mila 21-4-7, Yara), precipitation and soil characteristics are shown in Table 1. Soil temperature the first 1.5 months after seeding is shown in Figure 1.

To investigate the effect of the seed treatments the following measures were performed: (a) the number of plants in $2 \mathrm{~m} \times 5$ seeding rows per plots were determined at emergence and at 3, 7 and 21 days post-emergence (dpi); (b) crop stand was photographed in 2016 at BBCH 14-15 (Weber and Bleiholder 1990) to determine the development of crop stand cover; (c) manganese status of the plants were measured with a manganese scanner (NN-Easy55, NutriNostica, Frederiksberg C, Denmark) at BBCH 60; (d) biomass was determined by measurements with Yara's $\mathrm{N}$ sensor at $\mathrm{BBCH} 60$; (e) shoots and tap roots of 10 plants per plot were weighed; at $\mathrm{BBCH} 13$ and at $\mathrm{BBCH} 60$ in 2016; and at BBCH 60 in 2017; (f) yield, oil content and thousand seed weight (tsw) were determined at harvest; (g) soil temperature at seeding depth was followed by loggers (TinyTag, Intab, Stenkullen, Sweden).

The crop development was followed with digital scouting cameras (Scout Guard 550M-12, HD) on each field experiment location. 
Table 1. Location of field experiments, $\mathrm{N}$-application, dates of seeding and harvest, precipitation (from seeding to harvest), soil temperature at seeding, soil organic matter (OM), clay content and $\mathrm{pH}$ in soil

\begin{tabular}{|c|c|c|c|c|c|c|c|c|c|c|}
\hline \multirow[b]{2}{*}{ Year } & \multirow{2}{*}{ Location } & \multirow{2}{*}{$\begin{array}{l}\text { Longitude } \\
\text { Latitude }\end{array}$} & \multirow{2}{*}{$\begin{array}{c}\mathrm{N} \\
\left(\mathrm{kg} \mathrm{ha}^{-1}\right)\end{array}$} & \multicolumn{2}{|c|}{ Dates } & \multirow{2}{*}{$\begin{array}{l}\text { Precipitation } \\
\text { (mm) }\end{array}$} & \multirow{2}{*}{$\begin{array}{l}\text { Soil temp. } \\
\quad\left(C^{\circ}\right)\end{array}$} & \multirow{2}{*}{ OM (\%) } & \multirow{2}{*}{ Clay (\%) } & \multirow{2}{*}{$\mathrm{pH}$} \\
\hline & & & & Seeding & Harvest & & & & & \\
\hline \multirow{2}{*}{2016} & $\begin{array}{c}\text { Ödesberga, } \\
\text { Arboga }\end{array}$ & $\begin{array}{l}\text { N } 59.46 \\
\text { E } 15.83\end{array}$ & 120 & 8 May & 21 Sept & 193 & 16.5 & 6.0 & 40 & 6.9 \\
\hline & $\begin{array}{l}\text { Kräcklinge, } \\
\text { Örebro }\end{array}$ & $\begin{array}{l}\text { N } 59.18 \\
\text { E } 14.98\end{array}$ & 120 & $4 \mathrm{Apr}$ & 22 Sept & 335 & 11.9 & 3.9 & 29 & 6.4 \\
\hline \multirow{2}{*}{2017} & $\begin{array}{c}\text { Ödesberga, } \\
\text { Arboga }\end{array}$ & $\begin{array}{l}\text { N } 59.45 \\
\text { E } 15.79\end{array}$ & 120 & $11 \mathrm{Apr}$ & 27 Sept & 230 & 4.1 & 4.1 & 35 & 6.2 \\
\hline & $\begin{array}{c}\text { Åbyhammar, } \\
\text { Fellingsbro }\end{array}$ & $\begin{array}{l}\text { N } 59.48 \\
\text { E } 15.55\end{array}$ & 120 & 8 May & 26 Sept & 207 & 7.3 & 4.6 & 32 & 6.3 \\
\hline
\end{tabular}

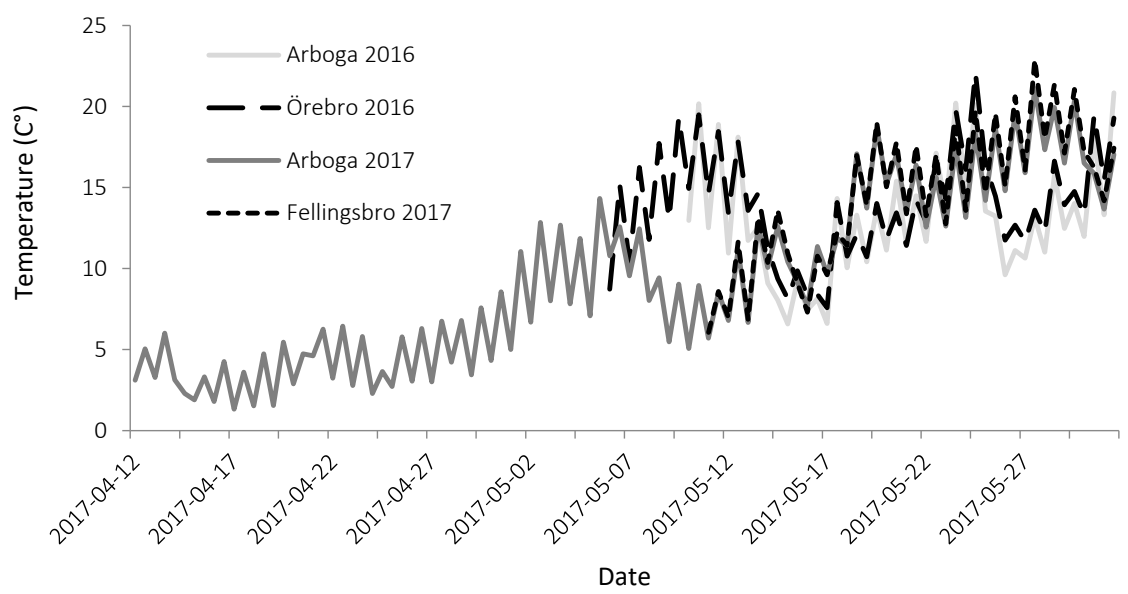

Fig. 1. Soil temperature at $2 \mathrm{~cm}$ depth at the four field experiment sites

\section{Statistical analyses}

Statistical analyses were performed using JMP 9.0 (SAS Institute 2010). A mixed linear model, adjusted with main effects and interaction as fixed factors and 'block (site)', as a random factor, was used. When the $F$-value was significant, for the main effects and interactions of the fixed factors, pairwise comparisons with Student's t-test were performed to identify significant differences $(p<0.05)$ among the means. Contrast analyses between controls and the average of treatments were also performed. Results from the field experimental site in Örebro 2016 were not used due to the extensive occurrence of weeds. Plant sampling at the Arboga experimental site in 2017 was not performed due to major frost damage and a reduced crop stand; however, the field experiment was harvested.

Since the treatments varied between the two years, i.e. in 2016 BFF was applied to all treatments while in 2017 there were also treatments without BFF, statistical analyses were performed on the results from the treatments + BFF in the two field experiments; Arboga 2016 and Fellingsbro 2017. Furthermore, statistical analyses on yields of seed and crude fat of the two experiments in 2017 were performed with all treatments included.

\section{Results}

\section{Seed mineral concentrations}

The mineral concentrations of seeds with and without application of BFF in 2016 are shown in Table 2. Seeds with BFF showed higher concentrations of $\mathrm{Cu}$, Fe and Al, principally originated from the binder and filler (Table 3); while the fungicide, Rovral $500 \mathrm{~A}$, had relatively low concentrations of the elements. 
Table 2. Concentration of mineral nutrients in seeds with (+) and without (-) treatment with binder (B), filler (F) and Rovral $(R), n=3$

\begin{tabular}{|c|c|c|c|c|}
\hline \multicolumn{2}{|c|}{ Nutrient } & $+\mathrm{BFF}$ & $-B F F$ & $p$-value \\
\hline$N$ & \multirow{7}{*}{$\begin{array}{l}\bar{\Sigma} \\
\text { o } \\
\text { o }\end{array}$} & 3.4 & 3.5 & ns \\
\hline$P$ & & 0.77 & 0.86 & ns \\
\hline K & & 0.69 & 0.73 & ns \\
\hline $\mathrm{Ca}$ & & 0.48 & 0.51 & ns \\
\hline $\mathrm{Mg}$ & & 0.29 & 0.32 & ns \\
\hline $\mathrm{Na}$ & & 0.015 & 0.015 & - \\
\hline$S$ & & 0.40 & 0.44 & ns \\
\hline $\mathrm{Cu}$ & \multirow{6}{*}{ 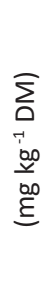 } & $61.7 \mathrm{a}$ & $3.9 \mathrm{~b}$ & 0.01 \\
\hline $\mathrm{Zn}$ & & 32.7 & 36.7 & ns \\
\hline B & & 11.9 & 13.0 & ns \\
\hline $\mathrm{Mn}$ & & 35.7 & 36.7 & ns \\
\hline $\mathrm{Fe}$ & & 90.7 a & $53.0 \mathrm{~b}$ & 0.041 \\
\hline $\mathrm{Al}$ & & $573.3 \mathrm{a}$ & $15.0 \mathrm{~b}$ & $<0.001$ \\
\hline
\end{tabular}

Table 3. Amount of $\mathrm{Al}, \mathrm{Fe}$ and $\mathrm{Cu}$ in binder, filler and Rovral applied to $1 \mathrm{~kg}$ of seeds, $\mathrm{n}=1$

\begin{tabular}{lccc}
\hline & $\mathrm{Al}$ & $\mathrm{Fe}$ & $\mathrm{Cu}$ \\
\hline Product & & $\left(\mathrm{mg} \mathrm{kg}^{-1}\right.$ seeds $)$ & \\
Binder & 13.2 & 0.88 & 64 \\
Filler & 55 & 6 & 0.0013 \\
Rovral & 0 & 0.0696 & 0.0019 \\
\hline
\end{tabular}

In 2017, the results of the analyses were consistent with the mineral nutrient content in the various seed treatment products (Table 4). There were no differences for $\mathrm{Na}\left(0.015 \%\right.$ of DM) and $\mathrm{Al}\left(15 \mathrm{mg} \mathrm{kg}^{-1} \mathrm{DM}\right)$ between the treatments (not shown).

Table 4. Concentrations of mineral nutrients in seeds of spring oilseed rape treated with various seed treatment products without the application of binder, filler and Rovral (-BFF), that were used in vigour tests and field experiments 2017, $\mathrm{n}=1$

\begin{tabular}{|c|c|c|c|c|c|c|c|c|c|c|c|c|}
\hline Treatment & $\mathrm{N}$ & $\mathrm{P}$ & $\mathrm{K}$ & $\mathrm{Ca}$ & $\mathrm{Mg}$ & $\mathrm{S}$ & $\mathrm{Cu}$ & $\mathrm{Zn}$ & B & $\mathrm{Mn}$ & $\mathrm{Fe}$ & Mo \\
\hline & \multicolumn{6}{|c|}{ (\% of DM) } & \multicolumn{6}{|c|}{$\left(\mathrm{mg} \mathrm{kg}^{-1}\right)$} \\
\hline Control (water) - BFF & 4.2 & 0.83 & 0.83 & 0.47 & 0.34 & 0.54 & 3.0 & 46 & 11 & 40 & 51 & 0.6 \\
\hline Omex Canola - BFF & 4.2 & 0.88 & 0.86 & 0.48 & 0.34 & 0.55 & 3.5 & 660 & 12 & 40 & 50 & 0.5 \\
\hline NoroTec raps - BFF & 4.2 & 0.81 & 0.86 & 0.48 & 0.36 & 0.57 & 3.0 & 47 & 36 & 340 & 52 & 20.0 \\
\hline $\begin{array}{l}\text { NoroTec Winter } \\
\text { Crop plus - BFF }\end{array}$ & 4.2 & 0.86 & 0.82 & 0.44 & 0.33 & 0.54 & 3.0 & 93 & 10 & 190 & 48 & 0.7 \\
\hline NoroTec Zn - BFF & 4.2 & 0.82 & 0.88 & 0.48 & 0.35 & 0.56 & 3.2 & 1200 & 11 & 43 & 51 & 0.6 \\
\hline Yara F3493 - BFF & 4.2 & 0.87 & 0.96 & 0.49 & 0.36 & 0.60 & 3.0 & 48 & 12 & 610 & 53 & 0.5 \\
\hline Yara F3501 - BFF & 4.2 & 0.86 & 0.92 & 0.50 & 0.35 & 0.59 & 3.0 & 810 & 12 & 41 & 52 & 0.5 \\
\hline Yara F3516 - BFF & 4.2 & 0.88 & 0.85 & 0.49 & 0.34 & 0.60 & 70 & 200 & 11 & 340 & 52 & 0.5 \\
\hline
\end{tabular}

\section{Seed vigour test}

The treatment with NoroTec ${ }^{\mathrm{TM}}$ WinterCrop plus + BFF showed the highest emergence rate on April 12, but not significantly higher than the control treatments with solely BFF, Omex Canola + BFF in 2016 (Table 5). The following days, April 13-14, there were fewer differences as only two treatments showed a lower emergence rate on April 14, i.e., NoroTec ${ }^{\mathrm{TM}}$ Raps + BFF and NoroTec ${ }^{\mathrm{TM}} \mathrm{Zn}+\mathrm{BFF}$. 


\begin{tabular}{|c|c|c|c|c|}
\hline \multirow[t]{2}{*}{ Treatment } & 12 April 16.00 & 13 April 8.00 & 13 April 16.00 & 14 April 8.00 \\
\hline & \multicolumn{4}{|c|}{ (\%) } \\
\hline Untreated control - BFF & $5 \mathrm{bc}$ & $68 \mathrm{a}$ & $82 \mathrm{a}$ & 93 a \\
\hline Control + BFF & $6 \mathrm{ab}$ & $68 \mathrm{a}$ & $79 a b$ & $92 a b$ \\
\hline Omex Canola + BFF & $9 a b$ & $70 \mathrm{a}$ & $77 a b c$ & $90 \mathrm{abc}$ \\
\hline NoroTec Raps + BFF & $2 \mathrm{~cd}$ & $46 c$ & $68 \mathrm{de}$ & $86 c$ \\
\hline NoroTec WinterCrop plus + BFF & $10 \mathrm{a}$ & $71 \mathrm{a}$ & $83 a$ & 95 a \\
\hline NoroTec $\mathrm{Zn}+\mathrm{BFF}$ & $0.5 \mathrm{~d}$ & $48 c$ & $61 \mathrm{e}$ & 88 bc \\
\hline Yara F3493 + BFF & $2 \mathrm{~cd}$ & 52 bc & $70 \mathrm{~cd}$ & 93 a \\
\hline Yara F3501 + BFF & $0.5 \mathrm{~d}$ & $57 \mathrm{abc}$ & $74 \mathrm{bcd}$ & $91 \mathrm{ab}$ \\
\hline Yara F3516 + BFF & $2 \mathrm{~cd}$ & $65 a b$ & $79 a b$ & $91 \mathrm{ab}$ \\
\hline$p$ & $<0.001$ & 0.002 & $<0.001$ & 0.015 \\
\hline CV & $68.3^{1}$ & 15.5 & 7.4 & 3.4 \\
\hline
\end{tabular}

Different letters indicate statistically significant differences within a column, $p<0.050$, Student's t-test

In 2017, the treatment with water - BFF showed the significantly highest emergence rate at the first reading in the morning of April 4 (Table 6). In the afternoon the emergence of Omex Canola + BFF showed similar emergence as the treatment with water - BFF. The following day, April 5, the emergence of the treatment with water - BFF was not significantly different from the untreated control - BFF, Omex Canola + BFF, NoroTec ${ }^{\mathrm{TM}}$ Winter Crop plus - BFF and NoroTec ${ }^{\mathrm{TM}} \mathrm{Zn}-\mathrm{BFF}$. On April 6 there were no significant differences between any of the treatments.

Table 6. Average emergence of spring oilseed rape (cv. Majong) in a seed vigour test at various times. Seeds were treated with mineral nutrient products and with $(+)$ and without $(-)$ the application of binder, filler and Rovral (BFF), in 2017, $n=4$.

\begin{tabular}{|c|c|c|c|c|c|}
\hline Treatment & 4 April 8.30 & 4 April 16.00 & 5 April 8.30 & 6 April 8.00 & 7 April 8.00 \\
\hline & & & $(\%)$ & & \\
\hline Untreated control - BFF & $0.5 c$ & $18 \mathrm{bc}$ & $73 a b c$ & 88 & 89 \\
\hline Water - BFF & $6.0 \mathrm{a}$ & $26 a$ & 81 a & 90 & 92 \\
\hline Control + BFF & $1.0 \mathrm{c}$ & $12 \mathrm{~cd}$ & $69 \mathrm{bcd}$ & 89 & 91 \\
\hline Omex Canola - BFF & $0.01 \mathrm{c}$ & 4.1 def & 61 cdef & 83 & 87 \\
\hline Omex Canola + BFF & $3.5 \mathrm{~b}$ & $23 a b$ & $78 a b$ & 89 & 91 \\
\hline NoroTec Raps - BFF & $1.0 \mathrm{c}$ & 6.5 def & 59 def & 84 & 91 \\
\hline NoroTec Raps + BFF & $0.5 \mathrm{c}$ & $3 f$ & 52 efgh & 82 & 85 \\
\hline NoroTec WinterCrop plus - BFF & $1.0 \mathrm{c}$ & 11 cde & $73 a b c$ & 93 & 97 \\
\hline NoroTec WinterCrop plus + BFF & $0.6 \mathrm{c}$ & 7.9 def & 59 defg & 81 & 87 \\
\hline NoroTec Zn - BFF & $1.5 \mathrm{bc}$ & 11 cde & 70 abcd & 89 & 94 \\
\hline NoroTec Zn + BFF & $0.01 \mathrm{c}$ & 4.1 def & 63 cde & 89 & 91 \\
\hline Yara F3493 - BFF & $1.5 \mathrm{~b}$ & 10 def & 60 def & 87 & 93 \\
\hline Yara F3493 + BFF & $0.01 \mathrm{c}$ & 4.5 def & 42 hi & 81 & 92 \\
\hline Yara F3501 - BFF & $1.5 \mathrm{bc}$ & 6 def & $48 \mathrm{ghi}$ & 83 & 90 \\
\hline Yara F3501 + BFF & $1.5 \mathrm{bc}$ & 4 ef & $50 \mathrm{fgh}$ & 85 & 91 \\
\hline Yara F3516 - BFF & $1.5 \mathrm{bc}$ & 8 def & $50 \mathrm{fgh}$ & 81 & 89 \\
\hline Yara F3516 + BFF & $1.0 \mathrm{c}$ & 4.5 def & $39 \mathrm{i}$ & 77 & 88 \\
\hline$p$ & $<0.001$ & $<0.001$ & $<0.001$ & ns & ns \\
\hline CV & 106.4 & 53.2 & 13.4 & 9.9 & 7.3 \\
\hline
\end{tabular}




\author{
Field experiments \\ Plant size \\ Effect of mineral nutrition in + BRF treatments
}

Average biomass of plant parts (shoots and roots), root length at $\mathrm{BBCH} 60$ and yields of seed and crude fat in the various seed treatments with BFF in the field experiments, located at Arboga 2016 and Fellingsbro 2017, are shown in Table 7. All treatments with mineral nutrients showed higher dry matter (DM) biomass than the control + BFF; however, the difference was not always significant. The highest root biomass was found in the Yara 3501 + BFF treatment, but was not significantly higher than Yara $3493+$ BFF, NoroTec ${ }^{\mathrm{TM}}$ Raps + BFF and NoroTec ${ }^{\mathrm{TM}} \mathrm{Zn}+$ BFF treatments. For shoots, all treatments with mineral nutrients except NoroTec ${ }^{\mathrm{TM}}$ Winter Crop plus + BFF and NoroTec $^{\text {TM }} \mathrm{Zn}+$ BFF showed significantly higher yield than the control + BFF. There were no significant differences in root length and yields of seed and crude fat (Table 7) between treatments.

No interactions between nutrient products and location (not shown) were found and there were no significant differences in plant size in the samples collected at BBCH 13 in 2016 (not shown).

\title{
The effect of binder, filler and fungicide on plant size
}

The average biomass of 10 plants collected at BBCH 60 in all mineral nutrient treatments + BFF was significantly lower (39.4 g DW) compared with the treatments - BFF (43.6 g DM) (not shown) in the field experiment at Fellingsbro 2017. There were no significant differences between the mineral nutrient treatments and no significant interactions between BFF and mineral nutrient treatment (not shown). There were no significant differences found in root biomass between all treatments.

\section{Emergence, manganese status, $\mathrm{N}$-sensor measurement and soil cover}

There was no difference in time of emergence, manganese status, biomass in 2016 by photography at BBCH 14-15 and $\mathrm{N}$-sensor measurements at $\mathrm{BBCH} 60$, between the seed treatments at any of the field sites (not shown).

\begin{tabular}{|c|c|c|c|c|c|}
\hline Main effects & $\begin{array}{c}\text { Root BM } \\
\text { (g DW) }\end{array}$ & $\begin{array}{l}\text { Shoot BM } \\
\text { (g DW) }\end{array}$ & $\begin{array}{l}\text { Root } \\
\text { length } \\
(\mathrm{cm})\end{array}$ & $\begin{array}{c}\text { Seed yield } \\
9 \% \text { WC } \\
\left(\mathrm{kg} \mathrm{ha}^{-1}\right)\end{array}$ & $\begin{array}{l}\text { Crude fat } \\
\left(\mathrm{kg} \mathrm{ha}^{-1}\right)\end{array}$ \\
\hline \multicolumn{6}{|l|}{ Nutrient product } \\
\hline Control + BFF & $5.5 \mathrm{~d}$ & $29 c$ & 8.3 & 2164 & 1025 \\
\hline Omex Canola + BFF & $6.4 \mathrm{bcd}$ & $34 a b$ & 8.0 & 2089 & 987 \\
\hline NoroTec Raps + BFF & $6.6 \mathrm{abc}$ & $34 a b$ & 8.6 & 1998 & 947 \\
\hline NoroTec Winter Crop plus + BFF & $5.7 \mathrm{~cd}$ & $31 \mathrm{bc}$ & 8.3 & 2155 & 1013 \\
\hline NoroTec $\mathrm{Zn}+\mathrm{BFF}$ & 6.4 abcd & $32 \mathrm{abc}$ & 8.6 & 2014 & 960 \\
\hline Yara F3493 + BFF & $6.7 \mathrm{ab}$ & 35 a & 8.7 & 2111 & 994 \\
\hline Yara F3501 + BFF & $7.4 \mathrm{a}$ & $36 \mathrm{a}$ & 9.0 & 1988 & 941 \\
\hline Yara F3516 + BFF & $6.4 \mathrm{bcd}$ & 36 a & 8.2 & 2153 & 1011 \\
\hline$p$ & 0.010 & 0.035 & ns & ns & ns \\
\hline \multicolumn{6}{|l|}{ Location } \\
\hline Arboga 2016 & 6.3 & $27 \mathrm{~b}$ & $8.8 \mathrm{a}$ & 1986 & 946 \\
\hline Fellingsbro 2017 & 6.5 & 39 a & $8.1 \mathrm{~b}$ & 2182 & 1023 \\
\hline$p$ & ns & 0.018 & 0.020 & ns & ns \\
\hline $\mathrm{CV}$ & 14.4 & 13.2 & 8.6 & 10.3 & 9.5 \\
\hline
\end{tabular}


The effect of binder, filler and Rovral on yield

In the 2017 experiments, the addition of BFF in the seed treatments reduced the yield of seed and crude fat by $4 \%$ on average (Table 8). There was a significant interaction between seed treatment and nutrient product with significant differences in the treatments without BFF while there were no differences when BFF was applied. Control BFF, NoroTec ${ }^{\mathrm{TM}}$ Winter Crop plus - BFF, Yara F3493 - BBF, Yara F3501 - BFF and NoroTec ${ }^{\mathrm{TM}} \mathrm{Zn}$ - BFF had significantly

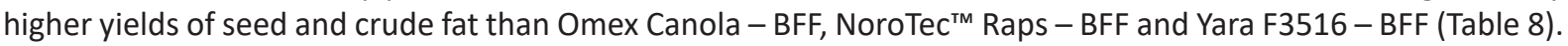

\begin{tabular}{|c|c|c|}
\hline Main effect and interactions & $\begin{array}{l}\text { Seed yield 9\% WC } \\
\qquad\left(\mathrm{kg} \mathrm{ha}^{-1}\right)\end{array}$ & $\begin{array}{l}\text { Crude fat yield } \\
\qquad\left(\mathrm{kg} \mathrm{ha}^{-1}\right)\end{array}$ \\
\hline \multicolumn{3}{|l|}{ Location } \\
\hline Arboga, $n=53$ & 2124 & 942 \\
\hline Fellingsbro, $n=64$ & 2205 & 1034 \\
\hline$p$ & ns & ns \\
\hline \multicolumn{3}{|l|}{ Seed treatment } \\
\hline$+\mathrm{BFF}$ & $2125 b$ & $968 b$ \\
\hline$-B F F$ & 2204 a & 1007 a \\
\hline$p$ & 0.008 & 0.010 \\
\hline \multicolumn{3}{|l|}{ Nutrient product } \\
\hline Control & 2196 & 1000 \\
\hline Omex Canola & 2104 & 963 \\
\hline NoroTec Raps & 2118 & 964 \\
\hline NoroTec Winter Crop plus & 2229 & 1015 \\
\hline NoroTec Zn & 2137 & 982 \\
\hline Yara F3493 & 2239 & 1019 \\
\hline Yara F3501 & 2183 & 993 \\
\hline Yara F3516 & 2111 & 963 \\
\hline$p$ & ns & ns \\
\hline \multicolumn{3}{|l|}{ Seed treatment $\times$ nutrient product } \\
\hline \multicolumn{3}{|l|}{$+\mathrm{BFF}$} \\
\hline Control + BFF & 2138 bcde & 976 cde \\
\hline Omex Canola + BFF & 2057 de & 940 de \\
\hline NoroTec Raps + BFF & 2111 bcde & 964 cde \\
\hline NoroTec Winter Crop plus + BFF & 2119 bcde & 966 cde \\
\hline NoroTec Zn + BFF & 2083 cde & 959 cde \\
\hline Yara F3493 + BFF & 2140 bcde & 969 cde \\
\hline Yara F3501 + BFF & 2144 bcde & 968 cde \\
\hline Yara F3516 + BFF & $2205 \mathrm{abcd}$ & $1006 \mathrm{abcd}$ \\
\hline \multicolumn{3}{|l|}{$-B F F$} \\
\hline Control - BFF & $2254 a b$ & $1023 \mathrm{abc}$ \\
\hline Omex Canola - BFF & 2151 bcde & 986 bcde \\
\hline NoroTec Raps - BFF & 2124 bcde & 965 cde \\
\hline NoroTec Winter Crop plus - BFF & $2340 \mathrm{a}$ & $1065 a b$ \\
\hline NoroTec $\mathrm{Zn}-\mathrm{BFF}$ & $2191 \mathrm{abcd}$ & $1006 \mathrm{abcd}$ \\
\hline Yara F3493 - BFF & $2337 a$ & $1070 \mathrm{a}$ \\
\hline Yara F3501 - BFF & $2222 a b c$ & $1017 \mathrm{abcd}$ \\
\hline Yara F3516-BFF & 2016 e & 920 e \\
\hline$p$ & 0.031 & 0.049 \\
\hline CV & 7.2 & 7.7 \\
\hline
\end{tabular}

Different letters indicate statistically significant differences within a column for a main effect or interaction, $p<0.050$, Student's t-test. There were no other significant interactions found between the main effects (not shown). WC = water content 
Treatments with NoroTec ${ }^{\mathrm{TM}}+$ BFF Winter Crop plus + BFF and Yara F3493 + BFF, reduced yield of seed and crude fat by about $10 \%$ compared with the same nutrient treatments without BFF (Table 8). There were no significant differences between the main effect; nutrient products and location, and there were no interactions between; location $\times$ seed treatment and location $\times$ nutrient product.

\section{Discussion}

An increased growth was found at $\mathrm{BBCH} 60$ (early flowering stage) in two of the field experiments when mineral nutrients were applied to seeds mixed with BFF, (Table 7), which was partly in accordance with hypothesis 1, i.e. that seed treatment with mineral nutrients will enhance germination and growth in SOR at low soil temperatures $\left(<10^{\circ} \mathrm{C}\right)$. Thus, these results confirm that an extremely small amount of mineral nutrient products applied to the seed has a positive effect on plant growth in a crop with high compensatory abilities as oil seed rape (Tatchell 1983, Angadi et al. 2003). However, the increased growth was not reflected in the seed yield and might just have been temporary.

The soil temperature at seeding the field experiments in 2016 , was slightly higher than intended, $12-17^{\circ} \mathrm{C}$, due to climatic and practical conditions; however, by mid-May the soil temperature decreased to $6-7{ }^{\circ} \mathrm{C}$ (Fig. 1 ). In 2017, the soil temperature was lower at seeding, $4-7{ }^{\circ} \mathrm{C}$ (Fig. 1). Thus, there were periods with cold conditions during early growth stages at all experimental sites. Despite the fact that the plants were larger at $\mathrm{BBCH} 60$ in the treatments with mineral nutrients and addition of BFF, there was no increase in yield of seed and crude fat (Table 7). The dry conditions that prevailed at the field experiment sites at Arboga 2016 and Fellingsbro 2017 (Table 1) might have been a disadvantage for plants with higher shoot biomass compared with relatively smaller plants consuming less water (Andersen et al. 1996). Larger plants probably have better resistance against high insect pressure than smaller plants, but since the presence of insects was generally low during both experimental years this effect was not seen. In the treatments with nutrient applications - BFF, at Fellingsbro 2017, there was no increase in plant growth at BBCH 60, as opposed to hypothesis 1 . Since the analyses confirmed that the nutrients adhered to the seeds without BFF, the application method was not the issue (Table 4).

Application of mineral nutrients did not have a great impact on plant emergence, as opposed to hypothesis 1 . There was a slight positive effect in the vigour test 2016, where NoroTec ${ }^{\mathrm{TM}}$ Winter Crop plus + BFF showed a higher rate of emergence compared with the untreated control - BFF; however, the difference was only found at the first reading (Table 5). Treatments with NoroTec ${ }^{\mathrm{TM}}$ Raps + BFF and NoroTec ${ }^{\mathrm{TM}} \mathrm{Zn}+$ BFF showed a slightly lower emergence rate than the other treatments in 2016. The vigour test in 2017 showed that only treatment with water-BFF improved emergence; however, within a few days there were no differences between the treatments. The differences in the vigour test were not reflected in the field experiments since no differences in emergence rate were found, neither was biomass production in early growth (BBCH 13) or manganese status affected (not shown). There are no standardised seed vigour tests that are suitable for all types of crops. The seed vigour tests can principally be used to investigate how seed quality, i.e. germination and emergence, is affected by a certain treatment and does not often reflect the growth under field conditions (Gupta 1993, Usha and Dadlani 2015).

The addition of BFF had a negative effect on yield of seed and crude fat. In the field experiments, yield of seed and crude fat decreased by $4 \%$ on average compared with the mineral nutrient products without BFF. For three of the products, NoroTec ${ }^{\mathrm{TM}}+$ BFF Winter Crop plus + BFF and Yara F3493 + BFF, the decrease by + BFF was 10\% (Table 8). The negative effects may be caused by the elevated concentrations of Fe and Al found in the binder and filler (Table 2). These elements may be toxic in high concentrations and they are also prone to form chemical complexes with other mineral elements that affect the germinating seed depending on which elements that are prevailing (Marschner 1995a,b, Schnoor 1996). Numerous Swedish farmers use seeds without application of BFF with success (Stoltz and Wallenhammar 2018), thus the application of BFF may thereby be questioned. The effects and needs of BFF application require further investigation. The economy of the farmer will be negatively affected by buying more expensive seed that is treated with BFF without obvious benefits; instead, the yield is reduced by $4 \%$.

Scientific reports on the effect of binder and fillers on emergence and plant growth is limited. Often the binder and fillers are applied by private seed companies, and the technology is owned by them and not available outside the company. Independent researchers are often interested in the active ingredients in the products for seed treatments and do not include binder and filler in their investigations (Ullah et al. 2002, Mirshekari 2010, Farooq et al. 2012, Imran et al. 2013, Seyvedi et al. 2015, Pedrini et al. 2017). Seed companies are, in general, more interested 
in the seed management and their investigations are primarily focused on flowability, adherence, dust-off and appearance, and collaborations between seed companies and independent researchers are rare (Pedrini et al. 2017).

The effect of the different nutritional products varied between the experimental sites and vigour tests. NoroTec ${ }^{\mathrm{TM}}$ $\mathrm{Zn}$, the only product without macronutrients except sulphur, showed similar effect as the other products as opposed to hypothesis 2 , i.e. that products with both macro- and micronutrients will enhance emergence and growth more than products with only micronutrients. Therefore, it is not possible to distinguish a specific product or element that stimulates seed emergence and growth. Some nutrients can inhibit emergence and growth. In a previous study where seeds of Ethiopian cabbage (Brassica carianata L.) were soaked in different solutions, the emergence and early growth was improved when the seeds were soaked in water, manganese sulphate and zinc sulphate, but was reduced in iron sulphate (Ullah et al. 2002).

Another factor that is likely to affect the outcome is the $\mathrm{pH}$ of the nutritional products. For the products included in this study $\mathrm{pH}$ was very low and ranged from 1.5 to 3.0, which could affect the seed and chemistry of the surrounding soil. Low $\mathrm{pH}$ can increase the availability of mineral nutrients such as manganese, zinc and copper (Schnoor 1996).

In conclusion, the results in this study showed that seed treatment with mineral nutrients may increase the plant size of SOR when the products are applied in combination with BFF, thereby contributing to more vigorous plants than without treatment. The increased growth might have increased seed yield during years with a high insect pressure, however it was not found here. There were no clear tendencies that one product was better than others, and thus the reason for the improved growth was not revealed. The use of BFF can be questioned; farmers often successfully use their own seed without any treatment and we found a decrease in seed and crude fat yields by, an average of $4 \%$ when BFF was applied to the seed. An improved collaboration between independent researchers and private seed companies could increase the conditions to develop binders and fillers that do not have a negative impact on growth and yield.

\section{Acknowledgements}

The project was founded by the Swedish Farmers' Foundation for Agricultural Research. Thanks to the project group; farmer Håkan Carlsson, Ödesberga, Arboga, Sweden, Bo Isacsson, NoroTec AB, Skurup, Sweden, Ingemar Gruveus, Yara, Malmö, Sweden and Abdel El Hadrami, Omex, Winnipeg, Canada for invaluable input in the project. Omex, Yara and Noro Tec AB are acknowledged for providing products for seed treatments, and Lantmännen Lantbruk for providing the seeds. Thanks to; Magnus Nilsson, seed technologist, Rural Economy and Agricultural Society, Bjärred, Sweden, Ulf Engman, field trial unit manager, HS Konsult AB, Örebro and Matilda Lönnemark, CEO, Frökontrollen AB, Örebro.

\section{References}

Andersen, M.N., Heidmann, T. \& Plauborg F. 1996. The effects of drought and nitrogen on light interception, growth and yield of winter oilseed rape. Acta Agriculturae Scandinavica, Section B - Soil \& Plant Science 46: 55-67. https://doi. org/10.1080/09064719609410947

Angadi, S.V., Cutforth, H.W., McConkey, B.G. \& Gan, Y. 2003. Yield Adjustment by Canola Grown at Different Plant Populations under Semiarid Conditions. Crop Science 43: 1358-1366. https://doi.org/10.2135/cropsci2003.1358

Ekbom, B. 2010. Pests and Their Enemies in Spring Oilseed Rape in Europe and Challenges to Integrated Pest Management. In: Williams I. (ed). Biocontrol-Based Integrated Management of Oilseed Rape Pests. Dordrecht: Springer. p. 151-165. https://doi. org/10.1007/978-90-481-3983-5_5

Engels, C. \& Marschner, H. 1992. Root to shoot translocation of macronutrients in relation to shoot demand in maize (Zea mays L.). Plant Soil 126: 215-225. https://doi.org/10.1007/BF00012825

Farooq, M., Wahid, A. \& Siddique K.H.M. 2012. Micronutrient application through seed treatments - a review. Journal of Soil Science and Plant Nutrition 12: 125-142. https://doi.org/10.4067/S0718-95162012000100011

Gupta, P.C. 1993. Seed vigour testing. In: Agrawal, P.K. (ed.) Handbook of seed testing. DAC, Ministry of Agriculture, Govt. of India, New Delhi. p. 242-249.

Imran, M., Mahmood, A., Römheld, V. \& Neumann, G. 2013. Nutrient seed priming improves seedling development of maize exposed to low root zone temperatures during early growth. European Journal of Agronomy 49: 141-148. https://doi.org/10.1016/j. eja.2013.04.001

Marcar, N.E. \& Graham, R.D. 1986. Effect of seed manganese on the growth of wheat (Triticum aestivum) under manganese deficiency. Plant and Soil 96: 165-173. https://doi.org/10.1007/BF02374761 
Marschner, H. 1995a. Functions of mineral nutrients: Micronutrients. In: Marschner, H. (ed). Mineral nutrition of higher plants London, UK: Academic Press. p. 313-404. https://doi.org/10.1016/B978-012473542-2/50011-0

Marschner, H. 1995b. Beneficial mineral elements. In: Marschner, H. (ed). Mineral nutrition of higher plants. London, UK: Academic Press. p. 405-435. https://doi.org/10.1016/B978-012473542-2/50012-2

Mirshekari, B. 2010. Seed priming with iron and boron enhances germination and yield of dill (Anethum graveolens). Turkish Journal of Agriculture and Forestry 36: 27-33.

Miyasaka, S.C. \& Grunes, D.L. 1990. Root temperature and calcium level effects in winter wheat forage: II. Nutrient composition and tetany potential. Agronomy Journal 82: 24-249. https://doi.org/10.2134/agronj1990.00021962008200020014x

Pedrini, S., Merritt, D.J., Stevens, J. \& Dixon, K. 2017. Seed Coating: Science or marketing spin? Trends in Plant Science 22: 106116. https://doi.org/10.1016/j.tplants.2016.11.002

Peltonen-Sainio, P., Kontturi M. \& Peltonen, J. 2006. Phosphorus seed coating enhancement on early growth and yield components in oat. Agronomy Journal 98: 206-211. https://doi.org/10.2134/agronj2005.0141

Rengel, Z. \& Graham, R.D. 1995. Importance of seed zinc content for wheat growth on zinc-deficient soil. I. Vegetative Growth. Plant Soil 173: 259-266. https://doi.org/10.1007/BF00011463

Sanches Pacheco, R., Fernandes Brito, L., Straliotto, R., Vidal Pérez, D. \& Paulo Araújo, A. 2012. Seed enriched with phosphorus and molybdenum as a strategy for improving grain yield of common bean crop. Field Crops Research 136: 97-106.https://doi. org/10.1016/j.fcr.2012.07.017

SAS Institute, 2010. JMP 9.0.0. Cary, NC, USA. CSAS Institute Inc.

Schnoor, J.L. 1996. Modeling trace metals. In: Environmental Modelling - Fate and Transport of Pollutants in Water, Air and Soil. New York: John Wiley \& Sons, Inc. p. 381-451.

Seyyedi, S.M., Khajeh-Hosseini, M., Moghaddam, P.R. \& Shahandeh, H. 2015. Effects of phosphorus and seed priming on seed vigour, fatty acids composition and heterotrophic seedling growth of black seed (Nigella sativa L.) grown in a calcareous soil. Industrial Crops and Products 74: 939-949. https://doi.org/10.1016/j.indcrop.2015.05.082

Stoltz, E. \& Wallenhammar, A.-C. 2014. Influence of boron in organic red clover (Trifolium pratense L.) seed production. Grass and Forage Science 69: 285-293. https://doi.org/10.1111/gfs.12072

Stoltz, E. \& Wallenhammar, A.-C. 2018. Strategi för lönsam och effektiv vårrapsodling- information om praktiska erfarenheter. 28 p. https://hushallningssallskapet.se/?projekten=strategi-for-lonsam-och-effektiv-varrapsodling-information-om-praktiska-erfarenheter, 16 October 2019. (in Swedish).

Tatchell, G.M. 1983. Compensation in spring-sown oil-seed rape (Brassica napus L.) plants in response to injury to their flower buds and pods. The Journal of Agricultural Science 101: 565-573. https://doi.org/10.1017/S0021859600038594

Thomson, B.D., Bell, R.W. \& Bolland, M.D.A. 2008. Low seed phosphorus concentration depresses early growth and nodulation of narrow-leafed Lupin (Lupinus angustifolius cv. Gungurru). Journal of Plant Nutrition 15: 1193-1214. https://doi. org/10.1080/01904169209364390

Ullah, M.A., Sarfraz, M., Sadiq, M., Mehdi, S.M. \& Hassan, G. 2002. Effect of pre-sowing seed treatment with micronutrients on growth parameters of Raya. Asian Journal of Plant Sciences 1: 22-23. https://doi.org/10.3923/ajps.2002.22.23

Usha, T.T. \& Dadlani, M. 2015. Evaluation of seed vigour in soybean (Glycine max). Legume Research 38: 308-312. https://doi. org/10.5958/0976-0571.2015.00115.0

Weber, E. \& Bleiholder, H. 1990. Erläuterungen zu den BBCH- Dezimal-Codes für die Entwicklungsstadien von Mais, Raps, FabaBohne, Sonnenblume und Erbse- mit Abbildungen. Gesunde Pflanzen 42: 308-321. (in German).

Williams, I.H. 2010. The Major Insect Pests of Oilseed Rape in Europe and Their Management: An Overview. In: Williams I. (ed.). Biocontrol-Based Integrated Management of Oilseed Rape Pests. Dordrecht: Springer. p. 1-43. https://doi.org/10.1007/978-90481-3983-5_1 